\title{
An Analysis of the Quality of the Central American Strategy for Rural Territorial Development (ECADERT) as a Regional Public Policy
}

Luis Antonio Fernández Portillo*

Francisco Santos Carrillo**

doi:I0.III44/Javeriana.cdrı2-76.aqca

Recibido: 2015-03-03 Aprobado: 2015-07-21 Disponible línea: 2015-10-01

Cómo citar este artículo: Fernández-Portillo, L. A., \& Santos-Carrillo, F. (2015). An analysis of the quality of the Central American Strategy for Rural Territorial Development (ECADERT) as a regional public policy. Cuadernos de Desarrollo Rural, I2(76), 85-107. http://dx.doi.org/10.III44/Javeriana.cdri2-76.aqca

* Profesor titular de área en el Departamento de Organización de Empresas en la Universidad Loyola Andalucía, España E-mail: portillo@uloyola.es

** Investigador de la Fundación ETEA para el Desarrollo y la Cooperación. E-mail: francis.santos@ fundacionetea.org 


\begin{abstract}
The Central American Strategy for Rural Territorial Development is a regional policy regarding the rural territorial development of the Central American Integration System. A group of stakeholders was interviewed in order to analyze whether its different stages have characteristics that support the implementation and achievement of its desired goals. The results indicate that the design of this policy shows positive characteristics regarding the participatory process that involves the major stakeholders. However, the situation is worse regarding the implementation, primarily because of its weak ties to integrate system institutions, lack of funding, and the low involvement of national governments.
\end{abstract}

\title{
Keywords:
}

rural territorial development; regional public policies; Central American Integration System

\section{Análisis de la Calidad de la Estrategia Centroamericana de Desarrollo Rural Territorial (ECADERT) como Política Pública Regional}

\section{Resumen}

La Estrategia Centroamericana de Desarrollo Rural Territorial es una política regional respecto al desarrollo rural territorial del Sistema de Integración Centroamericana. Se entrevistó un grupo de actores con el fin de analizar si sus diferentes etapas tienen características que apoyan la implementación y el logro de las metas esperadas. Los resultados indican que el diseño de esta política muestra características positivas respecto al proceso participativo que involucra a los actores principales, sin embargo, la situación es peor respecto a la implementación, principalmente debido a la debilidad de los lazos que integran a las instituciones del sistema, la falta de financiación y la baja participación de los gobiernos nacionales.

\section{Palabras clave:}

desarrollo rural; políticas públicas regionales; Sistema de Integración Centroamericana 


\title{
Analyse de la Qualité de la Stratégie d'Amérique Centrale du Développement Rural Territorial (ECADERT) en tant que Politique Régionale
}

\author{
Résumé \\ La stratégie en Amérique Centrale du développement Rural Territorial est une politique régionale par \\ rapport au développement rural territorial du Système d'intégration Centroaméricaine. On a interviewé \\ un groupe d'acteurs avec l'objectif d'analyser si leurs différents moments ont les caractéristiques qui \\ soutient l'implémentation et l'obtention d'objectifs attends. Les résultats indiquent que le dessin de cette \\ politique montre les caractéristiques positives par rapport au processus participatif qui intègre aux acteurs \\ principaux, cependant, la situation est pire par rapport à l'implémentation, notamment dû à la faiblesse de \\ liens qu'intègrent aux institutions du système, le manque de financement et la moindre participation des \\ gouvernements nationaux.
}

Mots clés:

développement rural; politiques publiques régionales; Système d’intégration Centroaméricaine.

\section{Analise da qualidade da Estratégia Centro-americana para o Desenvolvimento Rural Territorial (ECADERT) como política pública regional}

\begin{abstract}
Resumo
A Estratégia Centro-Americana para o Desenvolvimento Rural Territorial é a política regional no que diz respeito do desenvolvimento rural territorial do Sistema da Integração Centro-Americana. Uma turma de investidores foi entrevistada a fim de analisar se os diferentes estágios têm características que apoiam a implementação e cumprimento dos escopos desejados. Os resultados sugerem que o desenho desta política apresenta características positivas a respeito dos processos participativos que envolvem os principais investidores. No entanto, a situação piora a respeito da implementação, primeiro porque das suas fraquezas pende a integração das instituições do sistema, falta de financiamento e baixo compromisso dos governos nacionais.
\end{abstract}

Palavras-chave:

Desenvolvimento Rural Territorial; políticas públicas regionais; Sistema da Integração Centro-Americana. 


\section{Introduction}

The Central American Strategy for Rural Territorial Development (Estrategia Centroamericana de Desarrollo Rural Territorial, ECADERT) is a public policy for rural development that takes a territorial approach. In this paper, public policies must be understood as the set of decisions and activities linked to the solution of a collective problem, the satisfaction of a demand, meeting a need, or an opportunity for public intervention (Dunn, 198I). An updated version of this approach defines public policy as the "actions and decisions taken by various actors to solve a problem politically defined as public” (Subirats, Knoepfel, Larrue \& Varone, 2008, p. 38). From this point of view, ECADERT is clearly a public policy.

The Council of Ministers of the Central American Agricultural Council (CAC) approved ECADERT in March 20ro; subsequently, the Summit of Heads of State and Governments of the Central American Integration System (Sistema de la Integración Centroamericana, SICA) ratified this policy on June 19, 2010. ECADERT seeks to create opportunities and build the capacities of the rural population in Central America, in order to improve their lives as well as develop social institutions that foster supportive, inclusive, and sustainable development (CAC, 20I0). The scope of ECADERT addresses all SICA member countries (i.e., Belize, Costa Rica, El Salvador, Guatemala, Honduras, Nicaragua, Panama, and the Dominican Republic). The most active countries have been Belize, Costa Rica, and Guatemala. ECADERT is a sectoral positive integration policy of the SICA ${ }^{2}$. The greatest advances in this policy are related to its institutional component: regional and national Commissions have been instituted in all countries and certain territories have been selected to locally apply the rural territorial development (RTD) approach.

Integration develops as a complementary instrument to the state in terms of public policy as it is a more suitable space for the implementation of shared policies whose nature is beyond national borders. The legal framework of the Central American integration has binding legal mechanisms and regulations that enable the incorporation of regional policies into national processes; nevertheless, their adoption is not mandatory. Thus, the institutional coordinating mechanisms to resolve this situation have not been defined. The decision is in the hands of national governments. The agenda to re-launch the integration of SICA includes other positive sectoral policies, some of which are currently under analysis using the same

I Positive integration policies are those that seek to create new cooperation mechanisms, whereas negative policies seek to eliminate obstacles. 
methodology. However, ECADERT was the first policy analyzed using this approach because it is now in a more advanced stage.

Despite both conceptual and practical advances, a territorial approach to rural development remains to be established in Latin America. As Favareto (2006, p. I56) noted, “... the introduction of the adjective 'territorial' in the repertoire of non-governmental organizations, of state bureaucracy, and of social movements, is notably limited by its incorporation through a form of addition... and not as a sign of institutional change".

According to Meyer-Stamer (2004, p. 2), although the findings concerning local economic development projects can be transferred to rural development projects, many initiatives have never gone beyond planning and mobilizing stakeholders. Beduschi (2007, p. 22) explains that one cause of this situation is that policies do not meet the actual demands of the territories (i.e., a proper identification of beneficiaries' needs has not occurred). However, the reasons for the low level of implementation can be found in the flaws of any of the other stages of the policy cycle: design, implementation, monitoring, and evaluation $(\mathrm{M} \& \mathrm{E})$.

While the implementation of ECADERT is ongoing, it is necessary to analyze whether this policy has flaws that jeopardize its implementation and the achievement of real effects in Central America. This study analyzed the different stages of ECADERT to find items that might help its implementation and achieve its goals. Conclusions can be drawn to form a basis for the construction of a conceptual framework regarding the design and implementation of supranational (and, indirectly, national) public policies for RTD.

The analysis proposed is not a classical evaluation; rather, it is a review of the process of building a policy, seeking to provide an analytical tool for policy makers. This objective is relevant because a catalog of policies is being defined in the same regional space where difficulties and delays in implementation processes have been detected. Furthermore, a classical evaluation tends to focus more on the outcomes and effects of a policy, whereas the analysis completed in this paper focuses on the whole policy cycle, including identification and design. A classical evaluation might not establish the origin of the policy or how stakeholders were involved in its design.

First, we present the theoretical framework of RTD and its standing in Latin America, in general, and Central America, in particular. Subsequently, we discuss the methodology used to analyze the different stages of ECADERT. Next, we present the results of the analysis. We conclude with a section that explains the major conclusions of the study. 


\section{Theoretical framework}

The failure of traditional development initiatives to confront poverty in rural areas and the growing inequality in rural income distribution (De Janvry \& Sadoulet, 2004, p. I) have encouraged the exploration of other methods to mitigate this structural weakness. The focus of RTD, which is the framework of ECADERT, seems suitable for Latin America because it is consistent with the changes observed in rural poverty and enables new opportunities to reduce it (De Janvry \& Sadoulet, p. II). Several success stories using the territorial approach support this idea.

The development of previous approaches (Table I), especially recently, has depended heavily on three key issues that remain applicable in Latin America. The first issue is the predominantly agrarian approach to rural development, which has greatly limited the potential to generate non-agricultural income in rural areas. The second issue concerns the consequences regarding the policies inspired by the Washington Consensus, which froze state funding for rural development; this outcome has influenced the chronic dependence of these countries on cooperation funds, and Central America is a clear example of this situation. Third, traditional approaches to rural development in the region limit participation among rural stakeholders who are the ultimate beneficiaries of these policies (Moscoso, 2006, p. 589).

TABle 1. Approaches to Rural Development in Latin America

\begin{tabular}{lll}
\hline \multicolumn{1}{c}{ PERIOD } & \multicolumn{1}{c}{ STAGES } & \multicolumn{1}{c}{ APPROACH TO RD } \\
\hline Until first half of the 20th century & “Hacienda” and plantations period & Community Development \\
\hline 50's and 60's of the 20th century & $\begin{array}{l}\text { Substitution industrialization } \\
\text { (SI) period, agrarian reforms } \\
\text { and colonization }\end{array}$ & $\begin{array}{l}\text { Generation and transfer of } \\
\text { technology. Green Revolution. } \\
\text { Agrarian reforms. }\end{array}$ \\
\hline 80's and 90's of the 20th century & $\begin{array}{l}\text { Economic liberalization period: } \\
\text { entry into a market economy. }\end{array}$ & $\begin{array}{l}\text { Production systems. Integrated } \\
\text { Rural Development }\end{array}$ \\
\hline $\begin{array}{l}\text { Failure of the SI model } \\
\text { From 90's until the end }\end{array}$ & $\begin{array}{l}\text { Free market period with structural } \\
\text { adjust and scarce State intervention. } \\
\text { Washington Consensus }\end{array}$ & $\begin{array}{l}\text { Freeze of Rural Development. } \\
\text { Social compensation funds }\end{array}$ \\
\hline & $\begin{array}{l}\text { Free market period with international } \\
\text { openness and insertion. Partial } \\
\text { reactivation of the role of the State. } \\
\text { Regional integration initiatives } \\
\text { as a response to globalization }\end{array}$ & $\begin{array}{l}\text { Social compensation funds. } \\
\text { Rural Territorial Development }\end{array}$ \\
\hline $\begin{array}{l}\text { From beginning of the 2Ist } \\
\text { century until today }\end{array}$ & & \\
\hline
\end{tabular}

Source: Moscoso, 2006: 590, and the authors 
The debate regarding RTD reached Latin America in the early 2ist century through international cooperation agencies. These were primarily based on the experience of Europe via the LEADER initiative, which was adapted to Latin America through research and reflection conducted at different think tanks (Samper \&Torrens, 20I5). The salient features of this approach are its multidimensional character (which integrates economic, sociocultural, environmental, and institutional aspects of development); the promotion of a multi-sectoral approach to economic development; and its relevance to participatory processes that involve all territorial actors that use models for public-private consultation (Sumpsi, 2006c, p. 3; CAC, 2010, p. 4).

RTD has specific features in Latin America. First, it is heavily influenced by the need to reduce poverty (Sumpsi, 2006b, p. 42). Second, a shared approach to RTD has not been conducted. The result is numerous isolated projects driven by actors and territorial policies that have been poorly articulated, with each following its own methodology and promoting a distinct institutional model. Weak institutions in many countries have exacerbated this situation by interrupting initiative continuity. These factors have ensured that the productive and institutional aspects have received the most attention from the major authors studying RTD in Latin America (e.g., Schejtman \& Berdegué, 2004; Sumpsi, 2006a). The third feature was noted above, and it is what inspired this study: initiatives have a high level of design but low levels of implementation and impact.

Certain Central American initiatives supporting the adoption of a territorial focus in rural development should be highlighted. The EXPIDER program ${ }^{2}$ served as a reference for disseminating the RTD model in Honduras and Costa Rica. IICA developed and adapted the doctrine to Latin America and disseminated the lessons from other experiences-such as those of Brazil and Mexico- to Central America (e.g., Sepúlveda, Rodríguez, Echeverri \& Portilla, 2003). The Regional Unit for Technical Assistance (RUTA, an initiative of the Central American Ministries of Agriculture specializing in rural development) technically and financially supported the design of the RTD strategy in Belize and promoted and financed ECADERT. Finally, Spanish cooperation through the Spain-SICA Fund (the financial instrument under SICA that directs the Spanish Agency for International Cooperation for Development with the region) clearly supported the RTD by providing financial resources for

\footnotetext{
2 The first phase, Pilot Experiences of Local Rural Development in Latin America, occurred between 2004 and 2005 in Bolivia, Ecuador, and Honduras; the second phase, Innovative Experiences in Rural Territorial Development, occurred between 2007 and 2008 in Venezuela, Costa Rica, and Chile.
} 
ECADERT and serving as a link between different think tanks and experts working on this approach in Central America and other parts of the world.

Certain non-governmental organizations (NGOs) working in the region have adopted the RTD approach for some of their programs and projects (e.g., the Fundación ETEA para el Desarrollo y la Cooperación and Ayuda en Acción”); in most cases, however, the influence of NGOs on national or regional policies is tenuous, and their institutional weaknesses hinder their effective participation in these type of processes. Subsequently, their ability (and willingness) to promote a territorial approach in Central America is limited. In general terms, most NGOs have been reluctant with regard to Latin American integration processes because they somehow regard these processes as an outcome of the neoliberal agenda.

The prevailing view regarding the territorial approach is not to adopt it as a guiding principle of national rural development policy but as a partial component of this policy. However, the literature typically pays closer attention to the territorial level than the national level, which is typically conceived as secondary to the local level (Echeverri \& Ribero, 2002, p. 153) without clearly developing how to design or implement a national (or supranational) RTD policy in methodological terms. Many authors acknowledge that the territorial approach requires high institutional complexity (Schejtman \& Berdegué, 2004, p. 40), but their proposals have focused on territorial rather than national institutions.

For some authors (e.g., Sepúlveda et al., 2003, p. II8), it is not necessary for a national rural development policy to follow an explicit design; rather, it must result from the set of macroeconomic, sectoral, and regional policies articulated in the development strategy adopted by the country as a whole (i.e., a "country vision"). A national RTD policy focuses on establishing a procedure to bring coherence to this heterogeneous set of policies, without specific considerations at the methodological or institutional level. For example, Echeverri and Ribero (2002, p. 153) propose that the function of national RTD policy should be to guarantee territorial and social cohesion while ensuring institutional development at the national and territorial levels. In turn, Amador (2012, p. 10) defines the contents of public policy (understood to be at the national level) for RTD as follows: identifying the territories where this development approach will be adopted; establishing the rules of the game; financing the organization of actors in the territory and the projects to be created; and establishing

3 Both NGOs actively participate in the implementation process of ECADERT. 
the mechanisms to provide the territory with sectoral policies. The same statement might be valid for a regional public policy.

This conceptual gap at the national level is even greater at the supranational level. For example, Echeverri and Ribero (2002, p. 155 ) note the "urgent need to work on strengthening the institutions that enable the rural sector to acquire a regional international perspective as well as the structures for political, economic, and trade relations that are more efficient and consistent with the current structure of internationalization”. They also emphasize the strategic necessity of deepening regional integration processes; however, they do not suggest that both institutional strength and a deeper integration would be enhanced through a regional RTD policy. In summary, most studies tiptoe around the national level, and hardly any enter the supranational level when making suggestions concerning the implementation of this approach.

The Central American integration process has defined a framework for economic integration based on the construction of an inchoate customs union. Unlike other models based on the signing of free trade agreements, the establishment of a customs union and its consequent shared external tariff provide some protection to regional producers against third parties. Moreover, implementing positive distributive integration policies might be possible in this institutionalized framework. Such is the case of ECADERT, which can mitigate the effect that arises from greater international integration. Finally, the sustainable development of territories is a priority for ECADERT, as it is making them more competitive and committed.

Regarding initiatives that encompass more than one country, the EXPIDER program and PIDERAL project ${ }^{4}$ did not have a mandate to build a supranational public policy; instead, they were intended to be "multi-country" demonstration projects that illustrate the benefits of the territorial approach. The lessons learned in this process (Sumpsi, 2006c; Samper \& Torrens, 2015, pp. 17-20) focus more on how to conduct a territorial project and how to link territories with the national policy than how to create and implement a national or supranational RTD policy.

Regarding the theoretical framework for the methodological analysis, it is not easy to locate proposals that satisfactorily evaluate the public policy processes that arise in the regional integration context. The ECADERT analysis is an illustrative example of this fact. It is a positive integration action that requires considerable effort in terms of initiative and policy coordination involving the use of numerous possible

\footnotetext{
4 The Innovative Policies for the Development of Rural Territories Project in Latin America was implemented between January 2012 and February 2014 in Costa Rica, the Dominican Republic, Ecuador, and Peru across eight rural areas (two in each country).
} 
indicators and a certain degree of complication in terms of their definition. However, the references available in the specialized literature regarding methodologies for using regional integration indicators are generally not conclusive or cannot be extrapolated.

In addition, most indicators refer to the European context (De Lombaerde \& Van Langenhove, 2006; Best, 2008) and are more concerned with measuring the effects of the integration process than the intrinsic quality of the corresponding policies; that is, they do not attempt to measure whether a policy has been created or implemented properly.

On the other hand, proposals exist to measure the quality of public policies; however, they are based on general secondary sources (Franco \& Scartascini, 2014) and reference the combined public policies of countries rather than specific policies for which data are often unavailable. Employing experts to analyze the quality of public policies is a method used in different contexts, sometimes in combination with secondary sources (Hallsworth, 20II). In the case of ECADERT, the lack of public evaluation reports has made it impossible to rely on related published secondary sources beyond the actual document that creates the policy. Nevertheless, we have been able to consult several unpublished reports on systematization (e.g., the minutes of the Regional Platform for Technical Assistance for the implementation of ECADERT, Plataforma Regional de Asistencia Técnica [PRAT]', meetings of the Regional Commission, among others) that served to deepen our understanding of the process.

Therefore, to analyze the quality of ECADERT, it has been necessary to create a set of specific indicators based on the ad hoc opinions of the stakeholders involved in this policy, as it will be shown in the following section.

\section{Methodology}

Given the scenario presented above, our proposal includes a set of 24 new indicators defined for this research and structured into the four classic stages of policy building (i.e., identification, design, implementation, and M\&E), thereby enabling an evaluation of the different dimensions of ECADERT.

These indicators were given to 20 qualified stakeholders (this figure requires one to carefully handle the calculated average values, especially at the institutional categories level) who participated throughout the ECADERT process at the highest levels

5 An advisory body with representatives of different regional and international institutions linked to ECADERT such as CAC, IICA, RUTA, and others. 
(Table 2).These stakeholders include the executive secretary of the Central American Agricultural Council; representatives from all participating PRAT institutions; the two main advisors of the Spain-SICA Fund; members of the Regional Commission (the body responsible for coordinating the monitoring and implementation of the Strategy, composed of two representatives per country: one from the public sector and another from civil society), and others. These stakeholders participated in one-on-one interviews conducted between July and December 2014. The interviews were based on a questionnaire concerning the indicators, and gave respondents the opportunity to clarify and discuss their answers. This qualitative information was used to refine the results and provide conclusions. Therefore, the analysis below is based primarily on the average values obtained from the points that the respondents awarded to the indicators, with refinements incorporated through their comments.

The number of qualified stakeholder respondents was restricted because of the size and nature of the process. However, we think that a procedure based on the opinions of key stakeholders can overcome some of the methodological weaknesses that we have noted. In the end, public perceptions of how integration functions end up influencing the development of the integration process itself in a system governed by democratic patterns. The information obtained is therefore of great interest to meet the objective of this study.

TABLE 2. Institutional classification of respondents

\begin{tabular}{|c|c|c|}
\hline Institution & No. & ROLES/INTERESTS \\
\hline SECAC* & 4 & $\begin{array}{l}\text { Main stakeholder, promotor of ECADERT. } \\
\text { A single point of view. }\end{array}$ \\
\hline PRAT* & 5 & $\begin{array}{l}\text { Representatives of different institutions (SECAC, } \\
\text { IICA, RUTA, CATIE, Fundación ETEA), } \\
\text { different points of views and interests. }\end{array}$ \\
\hline Spain-SICA Fund* & 2 & $\begin{array}{l}\text { Mainly financial support, monitoring the process. } \\
\text { Active role setting constraints and guidance for } \\
\text { the implementation. Inserted in the SICA General } \\
\text { Secretariat, with interests in other sectoral policies. }\end{array}$ \\
\hline $\begin{array}{l}\text { Andalusian International } \\
\text { Cooperation Agency }\end{array}$ & I & $\begin{array}{l}\text { Mainly financial support. Active role (technical assistance) in } \\
\text { certain territories where ECADERT is being implemented. }\end{array}$ \\
\hline Regional Commission & 7 & $\begin{array}{l}\text { Representatives of public institutions and CSO. } \\
\text { Different points of views and interests. }\end{array}$ \\
\hline RUTA* & I & Financial and technical support. \\
\hline
\end{tabular}

*Includes the head of the institution

Source: The authors 
Each indicator offers a predetermined set of values known as configurations. For every indicator, the respondents were asked to allocate ro points among the possible configurations to express their views of the current situation with regard to that indicator. The reason behind the ro-point allocation, instead of merely choosing the preferred configuration is so that the answers could be better differentiated. For example, for the indicator Origin, the Bottom-up configuration received an average of 6.4 points, whereas Top-down received 3.6. In this case, these results (together with the qualitative information gathered during the interviews) show that ECADERT primarily had a top-down origin; however, some less significant bottom-up processes were nevertheless present.

The catalog of indicators, configurations, and the points they received are shown in Tables 4-7 below.

In the Results section, we analyze the mean score for each configuration according to the criteria, based on a preference for certain configurations over others. Following the previous example, we consider Bottom-up preferable to Top-down for indicator Origin, given the participatory nature of RTD. We define the indicators and the preference criteria based on two sources: one that is objective and another that is subjective.

The objective source is derived from the requirements that define ECADERT as a Central American public policy, as it appears in the official document (CAC, 20I0). Three indicators are defined under this perspective: its scope, with a regional focus preferred over a partial or national focus; its degree of openness to participation from major stakeholders, with binding preferred over not binding; and its aspiration toward transparency and accountability in which processes defined and planned at the regional level are preferred. The subjective source is derived from our interpretation of the focus of these public policies within the framework of RTD and Central American integration. We understand RTD public policies, including ECADERT, within this new focus on multilevel participatory governance, which matches well with the philosophy expressed in the official document of ECADERT and allows implementation at the regional level. The indicators defined by this source are more numerous and related to autonomy, innovation, the design of a jurisdictional framework based on regional institutions, a planned legal framework, an institutional framework for implementation, the existence of mechanisms of ownership by countries, and others.

To complement this source, the rationale for preferring certain configurations over others is also based on three epistemological pillars. First, this rationale accounts for 
the nature of ECADERT so the configurations that define a preferable situation are based on the description of the objectives, content, and methodology of ECADERT as well as the institutional mechanisms required to make its implementation feasible in an area of governance such as SICA.

Second, we interpret ECADERT as a regional public benefit that aspires to be incorporated in the Central American record as a regional public policy. Since we understand ECADERT as a public policy, we introduce the normal variables used to determine the process of public policies in this analysis: identification of the policy; definition of the problem and objective; stakeholder participation; decision-making process; and evaluation of the policy.

Finally, the third pillar corresponds to our experience as agents of international cooperation with over 25 years of experience in Central American RTD and integration (Caldentey, 1999, 20I2, 2013 and 20I4; Caldentey \& Romero, 2010; Santos, 2013; Santos \& Pozo, 2013).

\section{Results}

Based on their configurations, the two formulation stages (identification and design) are closest to what we understand as a preferable situation; the stages with more distant configurations from this preferred situation are implementation, followed by $\mathrm{M} \& \mathrm{E}$ (see Table 3, based on the points received by configurations shown in Tables 4, 5, 6 and 7). Our analysis opens a debate on the degree of consistency between proper design and improper implementation. We argue that several factors such as the low coercive capability of regional institutions, the low incorporation of regional legislative agreements to national laws, and the low involvement of national governments, affect implementation. Nevertheless, one should also consider whether the design should have taken this possibility into account, given the regional policy framework and its relative novelty in Central American public policy.

\section{Identification stage}

Even while taking other factors into account, the influence of external actors might have played a key role in identifying the advisability of an RTD strategy for Central America (Table 4). Knowledge of other extra-regional experiences enriched this phase. Most respondents believed that, despite this external influence, stakeholders in the region also made a significant contribution to the process. 
TABLE 3. Factors that positively and negatively influence the implementation of ECADERT

\begin{tabular}{ccll}
\hline STAGE & \multicolumn{1}{c}{+} & - & - \\
\hline Identification & & Influence from & $\bullet$ Top-down origin \\
& external agents & & \\
& & & \\
& Central & & \\
& American \\
& creation & & \\
& &
\end{tabular}

\begin{tabular}{|c|c|c|c|c|}
\hline Design & 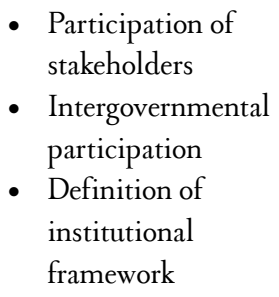 & $\begin{array}{l}\text { - Participation } \\
\text { of regional } \\
\text { consultive } \\
\text { bodies }\end{array}$ & $\begin{array}{l}\text { - Scarce clarity in } \\
\text { accountability } \\
\text { processes }\end{array}$ & $\begin{array}{l}\text { - Scarce clarity in } \\
\text { jurisdictional } \\
\text { framework } \\
\text { - Lack of } \\
\text { definition } \\
\text { of financing } \\
\text { mechanisms }\end{array}$ \\
\hline
\end{tabular}

\begin{tabular}{|c|c|c|c|}
\hline Execution & $\begin{array}{l}\text { - Schedule in } \\
\text { execution } \\
\text { - Participation of } \\
\text { stakeholders }\end{array}$ & $\begin{array}{l}\text { - Scheduling } \\
\text { mechanism } \\
\text { not effective }\end{array}$ & $\begin{array}{l}\text { - Low coercive } \\
\text { capacity } \\
\text { - Low } \\
\text { incorporation } \\
\text { of legislative } \\
\text { agreements } \\
\text { - Low } \\
\text { involvement } \\
\text { of national } \\
\text { governments }\end{array}$ \\
\hline$M \& E$ & $\begin{array}{l}\text { Relatively high } \\
\text { usefulness of } \\
\text { monitoring }\end{array}$ & $\begin{array}{l}\text { - } \begin{array}{l}\text { Execution } \\
\text { monitoring system }\end{array} \\
\text { - Medium level } \\
\text { of compliance } \\
\text { of monitoring } \\
\text { schedule } \\
\text { - Improvable } \\
\text { transparency and } \\
\text { accountability } \\
\text { processes }\end{array}$ & $\begin{array}{l}\text { - Lack of } \\
\text { definition } \\
\text { of a regional } \\
\text { evaluation } \\
\text { system }\end{array}$ \\
\hline
\end{tabular}

Key: ++: very positive influence; +: positive influence; -: negative influence; - -: very negative influence.

SOURCE: own elaboration 
The Innovation indicator refers to how the initiative that led to ECADERT was born. Some respondents discussed the clear influence of the European LEADER approach or the Brazilian Territorios de Ciudadanía (Territories of Citizenship) approach. However, the respondents indicated that ECADERT was a process largely adapted to the Central American reality from the beginning. Therefore, the indicator receiving the most points was Creation (4.5 vs. 3.0 for Replica of a foreign existing model vs. 2.6 for Formalization of a Central American existing process). Thus, the policy was considered as a new creation that arose to meet regional needs, rather than a mere replica of other contexts. Furthermore, the policy was also influenced by other contexts and it somehow formalized certain pre-existing initiatives. Therefore, although external stakeholders knew of these other contexts, ECADERT was largely an innovative process that involved more than adaptation to the Central American context.

The Top-down origin (6.4 vs. 3.6 for Bottom-up) might affect implementation, despite being the typical approach following integration processes. Had the policy emerged from SICA's technocracy rather than as a societal demand, it would be less responsive to the changes needed for implementation and would have fewer incentives to actively participate in the process. This situation might indicate that ECADERT contains the afore mentioned negative characteristic to the extent that rural development policies do not respond to the real demands of the territories. The fact that the Some countries configuration received the most votes under the Scope indicator (4.9 vs. 4.6 for Regional) confirms this assertion; thus, not all states saw the need to form a policy of this type. This factor might explain why ECADERT is not being properly implemented. Beyond this factor, no significant component was found during the initial stage to prevent proper strategy implementation. Although the Top-down origin might negatively influence implementation, this influence can be compensated in the design stage (see below).

TABLE 4. Indicators, configurations and average scores in the identification stage

\begin{tabular}{llc}
\hline \multicolumn{1}{c}{ INDICATOR } & \multicolumn{1}{c}{ CONFIGURATION } & SCORE \\
\hline \multirow{2}{*}{ ORIGIN } & Bottom-up & 3.6 \\
\cline { 2 - 3 } & Top-down & 6.4 \\
\hline \multirow{2}{*}{ AUTONOMY } & With influence of external actors & 5.4 \\
\cline { 2 - 3 } & Without influence of external actors & 4.6 \\
\hline \multirow{2}{*}{ INNOVATION } & Replica & 3.0 \\
\cline { 2 - 3 } & Formalization & 2.6 \\
\cline { 2 - 3 } & Creation & 4.5 \\
\hline \multirow{2}{*}{ SCOPE } & Regional (all countries) & 4.6 \\
\cline { 2 - 3 } & Some countries & 0.6 \\
\cline { 2 - 3 } & One country & \\
\hline
\end{tabular}

Source: own elaboration 


\section{Design stage}

Regarding the design stage (Table 5), one element that (in principle) can be considered positive is that respondents view the planned legal framework as binding on countries (6.I points). However, in SICA, a binding instrument might only be a regulation or regional agreement approved by the Council of Ministers of the CAC; however, this circumstance has not taken place. We tend to think that this confusion is related to the fact that ECADERT was approved by the Meeting of Presidents and endorsed by the Council of Ministers. Respondents equated what is approved with what is later implemented, which is common enough in institutional systems characterized by high levels of informality. For the implementation of ECADERT to be binding, one of the documented legal instruments defined by SICA must be formalized.

With regard to stakeholder participation, a consultation was performed to form the strategy (CAC, 20I0, pp. 32-33). This occurrence is positive because it is more likely that civil society and other stakeholders interested in implementation will collaborate in this process when they have been consulted during the design stage. However, a slight disagreement exists over whether this consultation was binding (5.I) or not (4.7). A non-binding consultation has less power to enlist the support of these groups for implementation purposes.

Although the original initiative arose from the regional technocracy, the process of drafting the strategy largely took a bottom-up approach. No information was provided in the strategy document regarding which specific territories were consulted or which representative process was used. Therefore, it cannot be categorically claimed that the approach is clearly bottom-up. A methodology that goes beyond mere consultation could have been followed (see Pérez et al., 2012, and 2014 for the development of the New Rural Strategy in Andalucía, Spain).However, the following process surely found a successful balance between cost and legitimacy. Nevertheless, the fact that the consultation was not clearly binding implies that the bottom-up design was not carried out to its full potential.

Binding intergovernmental participation in the design (8.6) is also positive. The fact that ministries, government agencies in the sector, and territorial representatives were consulted during this stage-and given that this consultation was binding- should be enough to support proper implementation. However, in most countries in the region, incoming elected governments do not necessarily continue the initiatives that belong to the outgoing government, therefore, the positive effect of the Binding configuration might be reduced.

Another positive element is the participation of regional consultative bodies, although, in this case, consultation was not binding (6.3) and might have been 
hampered by the institutional weakness of these bodies. Once again, this factor weakens the process as it moves toward implementation.

The respondents mostly understood that the institutional framework for implementing the strategy and its objectives are predefined (9.4). This fact undoubtedly favors implementation, although, in the latter case, the definition is general given that the establishment of indicators for results and deadlines is unknown.

Finally, the fact that a definition for a regional M\&E mechanism was proposed (6.3) might boost implementation. Nevertheless, it remains a mere proposal without actually materializing, eliminating any possible positive effect that it might have.

Perhaps the most important negative element is that the funding mechanisms for ECADERT are not defined (6.2). The dependence on international aid is a factor that clearly affects implementation. Despite the financial support received, a process of this magnitude requires the involvement of many stakeholders, beginning with the Central American governments themselves. The efforts undertaken by the executive secretariat of the Central American Agricultural Council (SECAC) and the SpainSICA Fund to establish a broad table of donors have not yet borne fruit.

The second factor that might negatively affect implementation is the lack of a welldefined accountability system for stakeholders (Regional system proposed received the highest score with 3.6 points). Although it is understood that reports from PRAT presented before the Regional Commission are an example that this mechanism does in fact exist, a clearly defined process with an unambiguous content and frequency is lacking. Moreover, although the Regional Commission is an appropriate body for receiving such information, it is likely that it is necessary to define a similar accountability procedure for PRAT, the various national committees, consultative bodies from SICA tied to the process, and the rest of society in general when one wants to encourage countries to take ownership.

Third, there is no clarity concerning the issue of jurisdiction. Although the evaluation concentrates on the configuration known as Explicit (6.2), this concentration was due to the high bias of the informants from the Regional Commission who were involved to a lesser degree in the design. The other groups that participated more actively in this phase opted for the Not explicit configuration, which showed a significant degree of confusion with regard to the knowledge and functioning of the SICA institutions. This statement was reinforced by the difference of opinions that also existed in the Jurisdiction Type indicator, where the Shared and Coordinated configurations received similar scores (4.7 and 5.0, respectively). In conclusion, if the jurisdictional framework of ECADERT is unclear and unknown to the major actors tied to it, then policy actions needed for implementation might not be properly designed or exercised. 
TABLE 5. Indicators, configurations and average scores in the design stage

\begin{tabular}{|c|c|c|}
\hline INDICATOR & CONFIGURATION & SCORE \\
\hline \multirow{2}{*}{ JURISDICTIONS } & Explicit & 6.2 \\
\hline & Not explicit & 3.9 \\
\hline \multirow{3}{*}{$\begin{array}{l}\text { PLANNED LEGAL } \\
\text { FRAMEWORK }\end{array}$} & Binding & $6 . \mathrm{I}$ \\
\hline & Not binding & 3.0 \\
\hline & Non-existent & I.O \\
\hline \multirow{4}{*}{ JURISDICTION TYPE } & Exclusive & O.I \\
\hline & Shared & 4.7 \\
\hline & Coordinated & 5.0 \\
\hline & Not defined & 0.2 \\
\hline \multirow{3}{*}{$\begin{array}{l}\text { PARTICIPATION OF } \\
\text { STAKEHOLDERS IN } \\
\text { THE DESIGN }\end{array}$} & Binding & 5.1 \\
\hline & Not binding & 4.7 \\
\hline & Non-existent & 0.2 \\
\hline \multirow{3}{*}{$\begin{array}{l}\text { INTERGOVERNMENTAL } \\
\text { PARTICIPATION }\end{array}$} & Binding & 8.6 \\
\hline & Not binding & $\mathrm{I} .2$ \\
\hline & Non-existent & 0.2 \\
\hline \multirow{3}{*}{$\begin{array}{l}\text { PARTICIPATION } \\
\text { OF REGIONAL } \\
\text { CONSULTATIVE BODIES }\end{array}$} & Binding & 3.6 \\
\hline & Not binding & 6.3 \\
\hline & Non-existent & 0.2 \\
\hline \multirow{3}{*}{$\begin{array}{l}\text { INSTITUTIONAL } \\
\text { FRAMEWORK FOR } \\
\text { IMPLEMENTATION }\end{array}$} & Defined & 7.2 \\
\hline & Ambiguous & 2.9 \\
\hline & Not defined & 0.0 \\
\hline \multirow{2}{*}{ OBJETIVES } & Defined & 9.4 \\
\hline & Not defined & 0.7 \\
\hline \multirow{2}{*}{ FUNDING MECHANISMS } & Defined & 3.8 \\
\hline & Not defined & 6.2 \\
\hline \multirow{5}{*}{$\begin{array}{l}\text { MONITORING AND } \\
\text { EVALUATION MECHANISM }\end{array}$} & Regional system defined & I.6 \\
\hline & Regional system proposed & 6.3 \\
\hline & Common national system proposed & 0.8 \\
\hline & Delegation to countries & 0.8 \\
\hline & Not defined & 0.6 \\
\hline \multirow{5}{*}{$\begin{array}{l}\text { TRANSPARENCY AND } \\
\text { ACCOUNTABILITY }\end{array}$} & Regional system defined & 2.8 \\
\hline & Regional system proposed & 3.6 \\
\hline & Common national system proposed & 0.7 \\
\hline & Delegation to countries & 0.5 \\
\hline & Not defined & 2.4 \\
\hline
\end{tabular}

Source: own elaboration 


\section{Implementation stage}

This phase (Table 6) includes an agenda that, in the respondents' opinions, is ongoing (7.8) and evidently favors implementation. Stakeholder participation (6.6 for Binding) is also considered as something positive that can support implementation.

However, some of the main indicators during this stage might show a low level of ECADERT implementation. First, it is understood that the coercive capacity of regional institutions is low (4.9) or nil (3.9). Public policies require aspects to link them to the exercise of state power. The effectiveness of a policy depends on whether the decisions made by institutions linked to the state or its subsidiaries (e.g., SICA), are mandatory and binding. In the case of ECADERT and SICA, however, a binding legal framework with the ability to force countries to take the necessary measures to implement this policy is not in place. The implication is that the implementation of the strategy depends almost exclusively on the political will of each country, which reduces the potential for synergistic work from the regional system and makes implementation more heavily dependent on national electoral outcomes.

In connection with the above findings, the partial (7.4) or non-existent (2.I) incorporation of regulatory agreements in the countries' laws, together with the limited budgetary support that they allocate for ECADERT (as shown by the majority of responses regarding Involvement configurations related to national governments: 7.0 for Partial and 3.I for Non-existent), seems to show that governments are not adopting the strategy as their regulatory framework for fostering rural development. Rather, it appears that two parallel processes might be happening in certain countries: first, the rural development of the country itself according to its own priorities and procedures, and second, the ECADERT process.

Therefore, the few positive elements and the abundance of negative aspects found during the implementation stage demonstrate that ECADERT is not being properly implemented, countries are not adopting it as the framework for rural development and they are also not performing the institutional and financial changes that it requires.

\section{M\&E stage}

The poor implementation described above might be offset by a system of M\&E (Table 7) that would bring attention to this situation and clearly identify its causes. However, the analysis of the indicators with regard to this last phase was not encouraging. In addition, note that the regional evaluation system exists only as a proposal that has not been defined yet. Nevertheless, certain monitoring activities are being performed. Therefore, the comments made below refer more to monitoring than evaluation. 
TABLE 6. Indicators, configurations and average scores in the implementation stage

\begin{tabular}{|c|c|c|}
\hline INDICATOR & CONFIGURATION & SCORE \\
\hline \multirow{3}{*}{ AGENDA } & In execution & 7.8 \\
\hline & Delayed & I.9 \\
\hline & Non-existent & 0.4 \\
\hline \multirow{4}{*}{ COERCIVE CAPACITY } & High & 0.0 \\
\hline & Medium & 1.3 \\
\hline & Low & 4.9 \\
\hline & No capacity & 3.9 \\
\hline \multirow{3}{*}{$\begin{array}{l}\text { INCORPORATION OF } \\
\text { REGULATORY AGREEMENTS }\end{array}$} & Wide & 0.5 \\
\hline & Partial & 7.4 \\
\hline & Non-existent & 2.1 \\
\hline \multirow{3}{*}{$\begin{array}{l}\text { INVOLVEMENT OF NATIONAL } \\
\text { GOVERNMENTS }\end{array}$} & Wide & 0.0 \\
\hline & Partial & 7.0 \\
\hline & Non-existent & 3.1 \\
\hline \multirow{3}{*}{$\begin{array}{l}\text { PARTICIPATION OF STAKEHOLDERS } \\
\text { IN EXECUTION }\end{array}$} & Binding & 6.6 \\
\hline & Not binding & 3.3 \\
\hline & Non-existent & O.I \\
\hline
\end{tabular}

Source: own elaboration

Regarding the scope of the system, although the Impact configuration received a relatively high score (4.7), the configuration with the highest scored was Execution (5.2); thus, the monitoring system seems to be focused on measuring the implementation of activities and not their impact.

In addition, compliance with the monitoring agenda was medium (7.7), meaning the activities related to monitoring are perceived as not conducted at specified intervals (i.e., they are erratic).

Third, although High was the most valued configuration with respect to the usefulness of the system (4.9), the Medium (3.6) and Low (1.5) configurations (when combined) received the majority of the points.

Finally, accountability was also perceived as an activity that lacked regularity and systematization, which is also less useful for stakeholders (5.2 for Medium and I.2 for Low regarding agenda compliance).

In conclusion, the M\&E (along with transparency and accountability) of ECADERT are activities that do not contribute to changing the negative situation perceived by respondents regarding its implementation. The current system barely enables the identification of the real causes of this situation. 
TABLE 7. Indicators, configurations and average scores in the M\&E stage

\begin{tabular}{|c|c|c|}
\hline INDICATOR & CONFIGURATION & SCORE \\
\hline \multirow{3}{*}{ SCOPE } & Impact & 4.7 \\
\hline & Execution & 5.2 \\
\hline & Non-existent & 0.1 \\
\hline \multirow{3}{*}{ COMPLIENCE OF M\&E AGENDA } & High & I.9 \\
\hline & Medium & 7.7 \\
\hline & Low & 0.5 \\
\hline \multirow{3}{*}{ USEFULNESS } & High & 4.9 \\
\hline & Medium & 3.6 \\
\hline & Low & I.5 \\
\hline \multirow{3}{*}{$\begin{array}{l}\text { COMPLIANCE OF TRANSPARENCY } \\
\text { AND ACCOUNTABILITY AGENDA }\end{array}$} & High & 3.6 \\
\hline & Medium & 5.2 \\
\hline & Low & I.2 \\
\hline
\end{tabular}

Source: own elaboration

\section{Conclusions}

The current analysis shows that ECADERT presents a clear imbalance between formulation and implementation. The elements that influence implementation most positively are concerned with the design that enables the participation of stakeholders and the governments of the involved countries as well as the definition of an appropriate institutional framework.

However, certain configurations of the design phase might negatively condition execution, such as the top-down origin and the absence of clear financing mechanisms. In addition, certain configurations selected by the respondents showed a SICA legal and institutional framework that would be favorable for implementation, but this view does not reflect reality. In the case of the indicators Jurisdictions, Planned legal framework, and Intergovernmental participation, the information available indicates that the situation is much less favorable than the respondents suggested. In SICA, the jurisdictions are not explicit, and its provisions are not binding unless a legislative measure is created for that purpose (which has not taken place in Central America).

The fact that certain respondents incorrectly assessed numerous factors also shows that a certain lack of knowledge exists regarding the framework of regional policies, which might also have a negative effect on execution. 
Therefore, the problem in this case is not that the ECADERT is a well-designed policy that is not being implemented; rather, certain deficiencies exist in its design, which are key for explaining the relatively low level of execution.

However, some other deficiencies exist in the remaining phases. In the implementation stage, the low coercive capacity of regional institutions, the low incorporation of regulatory arrangements, and the low involvement of national governments were also identified in the analysis as factors that might negatively affect the implementation of this policy.

Nevertheless, the elements that hinder implementation should not obscure the positive elements that have created some progress in the agenda, including the fact that a policy of this type is being implemented despite the above difficulties; a design that enables the participation of stakeholders and the governments of the involved countries; and the definition of an appropriate institutional framework. ECADERT has achieved some success in only syears, particularly with regard to the institutional framework, such as the establishment of the regional commission and the national commissions in all countries, and the selection of certain territories as pilots to apply the RTD approach locally.

The major lessons that might be useful for future policy formulations in SICA include the need for a better definition of the legal and institutional framework and the need to articulate a multilevel governance in the design of these policies. In short, a need exists to define a framework of supra-national power sin which national governments acquire greater responsibility and commitment.

The authors are currently configuring a quality index of the regional public policies of SICA based on the indicators and configurations described here. They are also designing a process to create recommendations that address the major deficiencies found in this policy based on consultations with a panel of experts.

\section{References}

Amador, F. (2012, July). Las políticas públicas como camino más seguro para un desarrollo [Public policy as a surest path to development]. Fórum DRS, I(2): Io. Retrieved from http://www.iica.int/Esp/regiones/andina/Ecuador/ Documentos\%20de\%20la\%20Oficina/Revista_Forum_DRS_Ediciono2.pdf Beduschi, L. C. (2007). El desarrollo territorial rural. Análisis de experiencias en Brasil, México y Chile [The rural territorial development. Analysis of experiences in Brazil, Mexico, and Chile]. In: F. Soto, L. C. Beduschi, y C. 
Falconi (Eds.), Desarrollo Territorial Rural. Análisis de experiencias en Brasil, Chile y México (pp. 17-47). Santiago de Chile: FAO.

Best, E. (2008).The Assessment of Regional Governance: principles, indicators and potential pitfalls. Draft Chapter for forthcoming GARNET Handbook on Monitoring and Analysing Regional Integration Processes. UNU-CRIS Working Papers W-2008/ı. Comparative Regional Integration Studies. Retrieved from http:// www.cris.unu.edu/fileadmin/workingpapers/WP-2008-I0.pdf

Caldentey, P. (1999). El desarrollo económico de Centroamérica en el marco de la integración regional [The economic development of Central America in the regional integration framework]. Tegucigalpa: BCIE.

Caldentey, P. (20I2). La integración regional, ámbito emergente de políticas de desarrollo en Centroamérica [Regional integration, development policies emerging field in Central America]. Revista española de Desarrollo y Cooperación, 30, 85-103.

Caldentey, P. (2013). La integración regional, marco de la cooperación horizontal en América Latina [Regional integration, horizontal cooperation framework in Latin America]. In: S. Arriola, R. Garranzo y L. Ruiz (Coord.), La renovación de la cooperación iberoamericana. Transformaciones para una agenda post 2015 [The renewal of the Ibero-American cooperation. Transformations for a post2015 agenda] (pp. 189-204). SEGIB and AECID.

Caldentey, P. (2014). Los desafios estratégicos de la integración centroamericana [Strategic challenges of the Central American integration]. Serie Estudios y Perspectivas N. 156. Sede Subregional de la CEPAL en México. México: CEPAL.

Caldentey, P., \& Romero, J. J.(Eds.). (2010). El SICA y la UE. La integración regional en una perspectiva comparada. Colección de estudios centroamericanos $\mathrm{N} .{ }^{\circ}$ I [Regional integration in a comparative perspective. Central American studies collection N. ㄷ]. Córdoba: Fundación ETEA para el Desarrollo y la Cooperación.

Central American Agricultural Council-CAC (2010). Central American Strategy for rural Area-Based Development 20I0-2030. ECADERT. Abridged Version. San José: IICA.

De Janvry, A., \& Sadoulet, E. (2004, July).Toward a territorial approach to rural development: International experiences and implications for Mexico's Microregions Strategy. Goldman School of Public Policy Working Paper. Retrieved from https://gspp. berkeley.edu/assets/uploads/research/pdf/Szekely_territorial_RD.pdf

De Lombaerde, Ph., \& Van Langenhove, L. (2006). Indicators of regional integration: conceptual and methodological aspects. In: De Lombaerde, Ph. (Coord.), Assessment and Measurement of Regional Integration, (pp. 9-4I). London: Routledge. 
Dunn, W. N. (198I). Public Policy Analysis: An Introduction. Englewood Cliff, N. J.: Prentice Hall.

Echeverri, R., \& Ribero, M. P. (2002).Nueva Ruralidad. Visión del territorio en América Latina y el Caribe [View of the territory in Latin America and the Caribbean]. San José: IICA.

Favareto, A. S. (2006). Paradigmas do desenvolvimento rural emquestão. Do agrárioao territorial (Tesis doctoral). Universidade de São Paulo, São Paulo. [Versión electrónica]. Retrieved from http://www.teses.usp.br/teses/ disponiveis/90/9013I/tde-24042008-II35I4/pt-br.php

Franco, M., \& Scartascini, C. (20I4). The Politics of Policies: Revisiting the Quality of Public Policies and Government Capabilities in Latin America and the Caribbean. Policy Brief No. IDB-PB-220. Washington D. C.: IDB.

Hallsworth, M., Parker, S., \& Rutter, J. (20II). Policy Making in the Real World. Evidence and Analysis. Institute for Government. Retrieved from http://www. instituteforgovernment.org.uk/publications/policy-making-real-world Meyer-Stamer, J. (2004). Governance and Territorial Development. Policy, Politics and Polity in Local Economic Development. Mesopartner Working Paper \#07. Retrieved from http://www.mesopartner.com

Moscoso, D. J. (2006). El proyecto de desarrollo rural EXPIDER. Las dificultades en la cuenca del Chanchán (Ecuador) [The rural development Project EXPIDER. Difficulties in the Chanchan basin (Ecuador)]. Revista de Fomento Social, (6I), 587-602. Pérez, P. P., Martín, J. M., \& Fernández, L. A. (20I2). El proceso de planificación del desarrollo rural: la Nueva Estrategia Rural para Andalucía [The planning process of rural development: the New Rural Strategy for Andalusia]. Revista de Fomento Social, (67), 9I-I22.

Pérez, P. P., Martín, J. M., Torres, M., \& Fernández, L. A. (20I4). Application of Prospective Analysis and Cluster Analysis as a Tool to Aid in the Design of Rural Development Policies: the Case of Andalusia. Cuadernos de desarrollo rural, II (73), 6I-86.

Samper, M., \& Torrens, J. (2015). Políticas públicas para el desarrollo de los territorios rurales [Public policies for the development of rural áreas]. In: P. van Dijck \& H. Nusselder (Coord.), Un recorrido por líneas locales: Aportes para políticas públicas en el sector rural de Centroamérica, el Caribe y la Región Andina [A tour of local lines: Contributions to public policies in the rural sector of Central America, the Caribbean, and the Andean Region] (Cap. I, 7-23). Retrieved from http://cdr.or.cr/libro/completo.pdf 
Santos, F., (20I3). La sociedad civil y la integración centroamericana. Colección de estudios centroamericanos N. 3 [Civil society and the Central American integration. Collection of Central American studies N. 3]. Córdoba: Fundación ETEA para el Desarrollo y la Cooperación.

Santos, F. \& Pozo, O. (20I3). El SICA: diálogos sobre una integración dinámica y singular en América Latina. Colección de estudios centroamericanos N. ${ }_{4}$ [SICA: dialogues on a dynamic and unique integration in Latin America. Collection of Central American studies N. 4]. Córdoba: Fundación ETEA para el Desarrollo y la Cooperación.

Schejtman, A., \& Berdegué, J. A. (2004). Desarrollo Territorial Rural. Debates y temas rurales N. ${ }^{\circ}$ [Territorial Rural Development. Debates and rural issues N. ${ }^{\circ}$ ] Santiago de Chile: RIMISP.

Sepúlveda, S., Rodríguez, A., Echeverri, R., \& Portilla, M. (2003). El enfoque territorial del desarrollo rural [The territorial approach to rural development]. San José: IICA. Subirats, J., Knoepfel, P., Larrue, C., \& Varone, F. (2008). Análisis y Gestión de Políticas Públicas [Analysis and Management of Public Policies]. Barcelona: Ariel. Sumpsi, J. M. (2006a). Desarrollo Territorial Rural: relaciones entre las transformaciones institucionales y productivas [Rural Territorial Development: relationships between institutional and productive transformations]. In: J. Bengoa (Comp.), Territorios Rurales. Movimientos sociales y desarrollo territorial rural en América Latina [Rural territories. Social movements and rural territorial development in Latin America] (pp. 86-ıго). Santiago de Chile: Catalonia.

Sumpsi, J. M. (2006b). Experiencias de desarrollo rural con enfoque territorial en la Unión Europea y América Latina [Rural development experiences with a territorial approach in the European Union and Latin America]. Estudios Agrosociales y Pesqueros, 209, 44-7I.

Sumpsi, J. M. (2006c). Experiencias Piloto de Desarrollo Local Rural en América Latina: Lecciones del Proyecto EXPIDER en Bolivia, Ecuador y Honduras [Pilot experiences of the Local Rural Development in Latin America: Lessons from the EXPIDER Project in Bolivia, Ecuador, and Honduras]. Documento de la Unidad de Desarrollo Rural del Banco Interamericano de Desarrollo N.․RUR-०6-०2. Washington D. C.: IDB. 